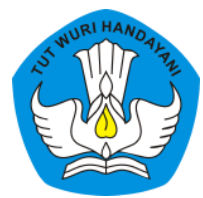

Page: 523-546

\title{
PEMBELAJARAN BERBASIS AKTIVITAS MATERI OPERASI PECAHAN DENGAN MENGGUNAKAN VISUALISASI GAPTEK
}

\author{
Tundung Memolo \\ Sekolah Menengah Pertama Negeri 3 Kepil Wonosobo, Jawa Tengah, Indonesia \\ Contributor Email: tundungmemolo@gmail.com
}

Received: Feb 15, 2021

Accepted: Apr 16, 2021

Published: Jul 30, 2021

Article Url: https://ojsdikdas.kemdikbud.go.id/index.php/didaktika/article/view/355

\begin{abstract}
Activity-based learning is a student-centered learning process that involves mental and psychological aspects through a variety of experiences. This study used GAPTEK visualization, namely physical activities of lining, cutting, pasting, and calculating. The purpose of this study was to describe how activity-based learning of fraction operation material using GAPTEK visualization, to find out how much the percentage of student positive responses, and the effectiveness of the learning in grade 7 students of $S M P$ Negeri 3 Kepil. The research method uses quasi-experimental research with data collection in the form of learning outcomes tests, observations and questionnaires. A significance value of $0.895>0.05$ indicates that the two groups are normally distributed and homogeneous. The significance value of the difference is $0.569>0.05$ which indicates that there is no difference between the pretest mean of the control and experimental groups. The learning description shows that students are actively involved in group discussions and share roles. The average percentage of students' positive responses related to activity-based learning about fraction operations using GAPTEK visualization was $95.3 \%$. Activity-based learning has been effectively used, which is shown by the experimental class average of 74.33 exceeding the value of 70.00 , and exceeding the average control class, namely 56.00. The difference in the increase in the average pretest and posttest experimental class was 37.33, more than the difference in the control class of 21.00 .
\end{abstract}

Keywords: Activities; Fractions; Learning; Visualization. 


\begin{abstract}
Abstrak
Pembelajaran berbasis aktivitas merupakan proses belajar terpusat pada siswa yang melibatkan aspek mental dan psikomotor melalui beragam pengalaman. Penelitian ini menggunakan visualisasi GAPTEK, yaitu aktivitas fisik menggaris, memotong, menempel, dan mengalkulasi. Tujuan penulisan artikel ini adalah mendeskripsikan bagaimana pembelajaran berbasis aktivitas materi operasi pecahan dengan menggunakan visualisasi GAPTEK, mengetahui seberapa besar persentase respon positif siswa, dan kefektifan pembelajarannya pada siswa kelas 7 SMP Negeri 3 Kepil. Metode penelitian menggunakan penelitian quasi eksperimen dengan pengambilan data berupa tes hasil belajar, observasi, dan angket. Nilai signifikansi 0,895 > 0,05 menunjukkan kedua kelompok adalah berdistribusi normal dan homogen. Nilai signifikansi perbedaan adalah 0,569 $>$ 0,05 yang menunjukkan bahwa tidak ada perbedaan antara rata-rata pretes kelompok kontrol dan eksperimen. Deskripsi pembelajaran menunjukkan bahwa siswa terlibat aktif dalam diskusi kelompok dan berbagi peran. Persentase rata-rata respon positif siswa terkait pembelajaran berbasis aktivitas materi operasi pecahan menggunakan visualisasi GAPTEK sebesar 95,3\%. Pembelajaran berbasis aktivitas terbukti efektif digunakan. Hal ini ditunjukkan oleh rata-rata kelas eksperimen adalah 74,33; melampaui nilai 70,00, serta melebihi rata-rata kelas kontrol yaitu 56,00. Perbedaan kenaikan rata-rata pretes dan postes kelas eksperimen sebesar 37,33 lebih dari perbedaan pada kelas kontrol sebesar 21,00.
\end{abstract}

Kata Kunci: $\quad$ ktivitas; Pecahan; Pembelajaran; Visualisasi.

\title{
A. Pendahuluan
}

Pembangunan pendidikan dasar (Suryadi, 2014) telah mereduksi konsep karakter dan kecakapan dasar anak sebagai pembelajar sepanjang hayat, menjadi semata-mata penyampaian teori dan penghafalan ranah kognitif tingkat rendah. Jika dibiarkan, mutu pendidikan tidak akan terwujud.

Djiwandono (2006) berpendapat bahwa seorang guru harus dituntut mengenal perkembangan kognitif, motivasi, psikologi sosial, serta bagaimana mengajarkan mata pelajaran tersebut. Demikian pula merencanakan tujuan pengajaran tanpa pertama-tama mengukur kemampuan siswa akan mengarah pada hal yang tidak perlu. Oleh karenanya, seorang guru harus memiliki pengetahuan tentang perkembangan kognitif siswa beserta kemampuannya.

Teori belajar Bruner (Suprijono, 2012) menunjukkan 3 tingkatan dalam belajar yaitu enaktif, ikonik, dan simbolik. Dengan pemahaman 
ketiga tingkatan di atas, penggunaan media keseharian (enaktif) yang mulanya dibangun dalam tahapan ikonik dalam sebuah proses pengkongkritan, akan menguatkan siswa dalam abstraksi simbolik.

Sayangnya, menurut Wena (2012) penggunaan metode ceramah masih disukai oleh guru dengan alasan hemat dalam penggunaan waktu, media, serta praktis dalam menyampaikan isi pembelajaran. Terlebih siswa hanya mendengarkan ceramah tanpa ada gambar yang menarik perhatian serta siswa hanya melihat kapur tulis yang berjalan. Akibatnya, siswa menjadi cepat bosan dan tidak memperhatikan materi yang disampaikan. Silberman (2009) juga menyatakan pembelajaran di kelas menunjukkan bahwa metode ceramah akan memberikan berkurangnya perhatian siswa seiring berlalunya waktu. Para siswa hanya mengandalkan pendengaran dan lambat laun siswa akan bosan. Jadi, pembelajaran bermakna tidak akan terjadi manakala siswa belajar dengan cara menghafal tanpa ada kesempatan untuk mempraktikkan.

Salah satu materi pelajaran matematika yang masih diajarkan dengan cara ceramah adalah materi operasi pecahan. Metode menghafal prosedur masih diterapkan. Akibatnya, pembelajaran pecahan menjadi kurang bermakna.

Menurut Suyono\&Hariyanto (2014) belajar bukan lagi penyampaian informasi dari guru ke siswa, namun siswa haruslah aktif mendapatkan pengetahuan baru dengan melibatkan mental dan aktivitas siswa. Belajar tidak pula harus kondisi formal di dalam kelas, namun dapat dilakukan kapan saja dan di mana saja.

Oleh karenanya diperlukan sebuah inovasi belajar yang menjawab tantangan mutu pendidikan yang berkualitas. Salah satu inovasi yang dikembangkan dalam pembelajaran materi pecahan adalah pembelajaran berbasis aktivitas menggunakan visualisasi GAPTEK. Pembelajaran ini dapat dilakukan di rumah selama pembelajaran jarak jauh.

Makna pembelajaran (learning) dibedakan dengan pengajaran (teaching). Menurut Suyono \& Hariyanto (2014) pembelajaran lebih berfokus kepada siswa sedangkan pengajaran lebih berfokus kepada guru. Pembelajaran 
dimaknai sebagai kegiatan aktif siswa membangun makna atau pemahaman. Dengan kata lain, pembelajaran adalah aktivitas siswa itu sendiri.

Degeng (melalui Wena, 2012) menjelaskan bahwa pembelajaran berarti upaya membelajarkan siswa. Penggunaan strategi inovasi pembelajaran sangat perlu, karena mempermudah proses untuk mencapai hasil optimal. Dalam proses pembelajaran, media yang digunakan harus mampu merangsang dan menumbuhkan minat siswa dalam belajar, sehingga interaksi siswa dengan media akan tumbuh yang dapat mempercepat proses pemahaman siswa.

Supriadie dan Darmawan (2013) menyatakan bahwa pembelajaran merupakan proses perubahan yang relatif permanen dalam suatu kecenderungan tingkah laku sebagai hasil praktik atau latihan. Jadi, dalam pembelajaran terdapat 3 esensi yaitu proses (pengalaman), perubahan tingkah laku atau pikiran, dan permanennya tingkah laku tersebut.

Berdasarkan pendapat di atas dapat dikatakan bahwa pembelajaran merupakan sebuah aktivitas siswa untuk memperoleh pengetahuan baru serta perubahan perilaku yang sifatnya permanen melalui proses atau pengalaman.

Silberman (2009) menjelaskan bahwa ketika belajar secara pasif, siswa mengalami proses belajar tanpa rasa ingin tahu, tanpa pertanyaan, dan tanpa daya tarik pada hasil. Namun, ketika belajar secara aktif, siswa akan melakukan sebaliknya sehingga terdapat tantangan mental.

Supriadie dan Darmawan (2013) menambahkan bahwa pembelajaran hakikatnya adalah aktivitas. Oleh karena itu, betapa pentingnya mengembangkan aktivitas pembelajaran yang bervariasi sehingga siswa dapat maksimal potensinya. Pembelajaran aktif dan inovatif (Munthe, 2014) membantu peserta didik menyimpan informasi hasil belajar ke dalam ingatan jangka panjang (long term memory). Hal ini dikarenakan working memory seperti memberikan pengodean, menemukan kembali, mengintegrasikan, guna menyimpan hasil belajar lebih tertanam.

Anwer (2019) mengemukakan bahwa pembelajaran berbasis aktivitas didefinisikan sebagai pengaturan kelas di mana siswa secara aktif berpartisipasi dalam pengalaman belajar daripada duduk sebagai pendengar pasif. Dalam 
pembelajaran ini, terjadi peran aktif dan keterlibatan siswa secara terusmenerus dan kolaborasi di antara siswa dalam lingkungan belajar. Dengan demikian, model mental yang memungkinkan kinerja tingkat tinggi seperti pemecahan masalah yang diterapkan dan transfer informasi dan keterampilan.

Tujuan PBA adalah membuat kelas lebih ramah siswa dan siswa tidak merasa terintimidasi (Kapur, 2019). Dalam hal ini, tugas pendidik adalah mengembangkan kesempatan bagi siswa untuk mempraktikkan pembelajaran inovatif. Guru juga harus memastikan bahwa tahapan aktivitas yang ada di RPP dapat terlaksana.

Berdasarkan penjelasan di atas, bahwa pembelajaran berbasis aktivitas (PBA) merupakan proses belajar terpusat pada siswa yang melibatkan aspek mental dan psikomoter melalui beragam pengalaman. Ciri-ciri PBA (1) mengacu pada pekerjaan yang melibatkan pengalaman langsung daripada studi buku teks; (2) siswa terlibat dalam pemrosesan informasi; (3) mengikuti teori konstruktivisme di mana siswa membangun pengetahuan sendiri; (4) mendorong partisipasi siswa dalam pelaksanaan tugas; serta (5) guru memastikan tahapan aktivitas dalam RPP dapat dilaksanakan.

Materi pecahan merupakan materi yang menjadi konsep dasar untuk menjamin kemampuan dasar. Menurut Hudojo (2005) Penekanan pemilihan materi lebih kepada pembentukan konsep dan struktur daripada sekadar teknik manipulasi sehingga siswa mengerti yang dipelajari. Hal ini harus menjadi perhatian guru matematika.

Dalam operasi pecahan terdapat 4 operasi tunggal, yaitu penjumlahan, pengurangan, perkalian, dan pembagian. Prinsip operasi penjumlahan dan pengurangan harus menyamakan penyebut, selanjutnya pembilang tinggal dijumlahkan atau dikurangi. Selanjutnya disederhanakan. Sedangkan pada perkalian 2 pecahan atau lebih, maka masing-masing pembilang dikalikan dan masing-masing penyebut dikalikan, selanjutnya disederhanakan. Pada penelitian ini, hanya 3 operasi tunggal yang dijalankan yaitu penjumlahan, pengurangan, dan perkalian. Sebagai materi prasyarat, siswa sudah mengenal pecahan yang senilai (As'ari, dkk., 2016). 


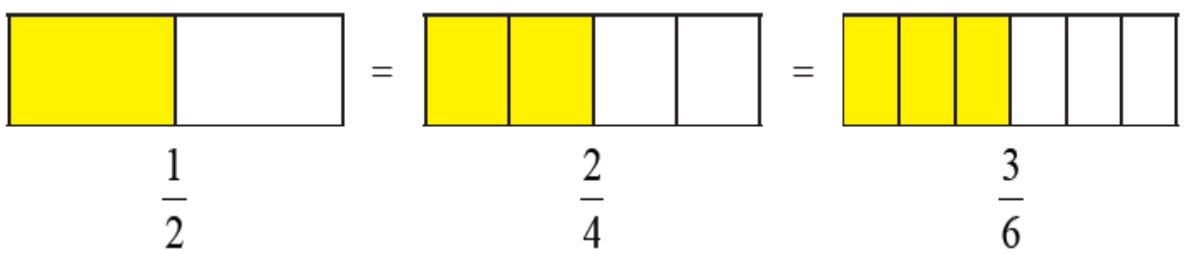

Gambar 1. Pecahan Senilai

Operasi penjumlahan pecahan dapat divisualisasikan sebagai berikut. (As'ari, dkk., 2016).
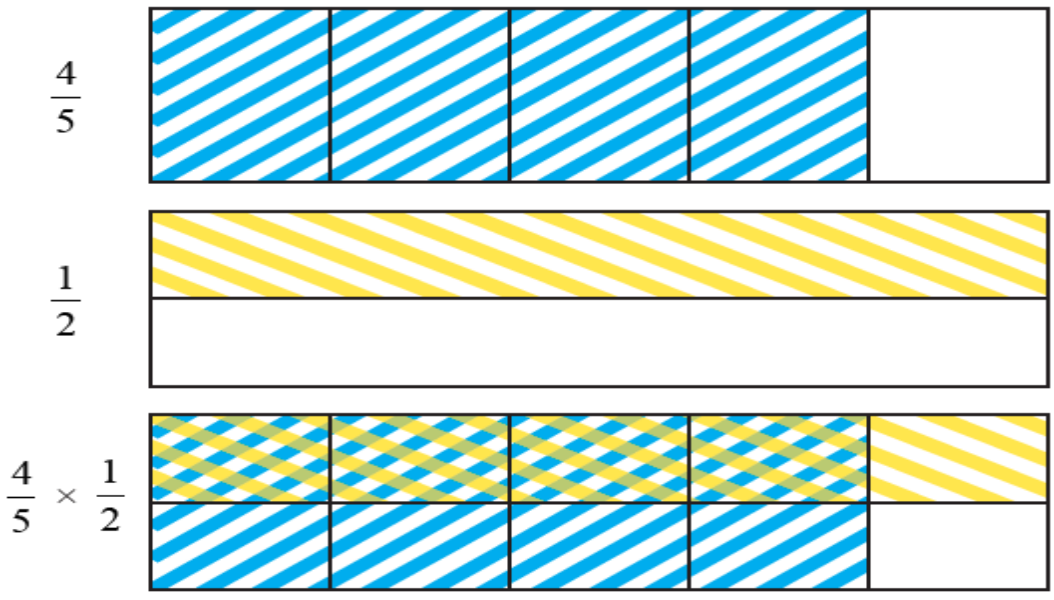

Gambar 2. Operasi Penjumlahan Pecahan

Operasi pengurangan pecahan dapat divisualisasikan sebagai berikut. (As'ari, dkk., 2016) :

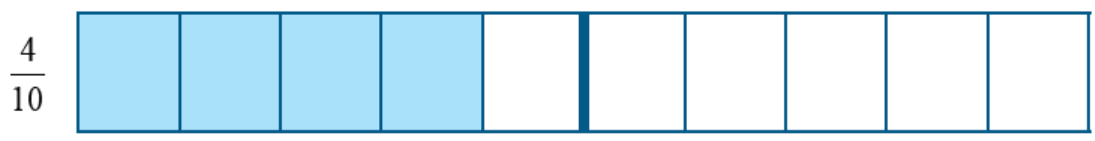

$+$

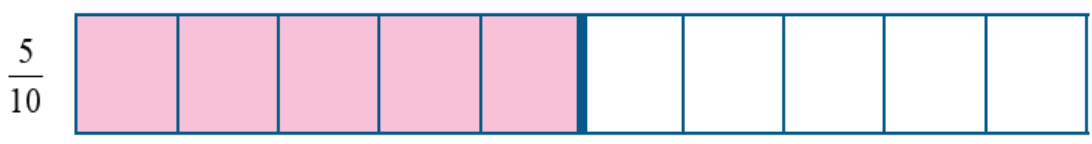

$=$

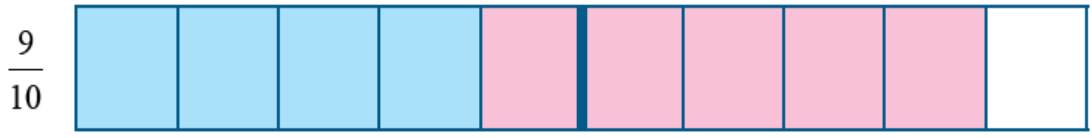

Gambar 3. Operasi Pengurangan Pecahan 
Sedangkan operasi perkalian, divisualisasikan sebagai berikut (As'ari, dkk., 2016) :
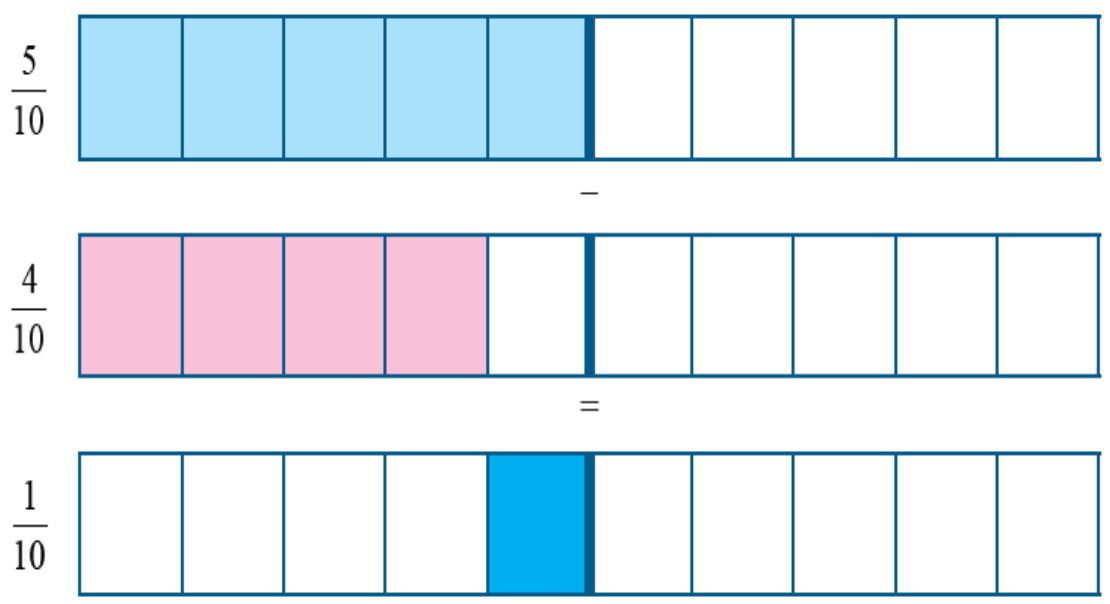

Gambar 4. Operasi Perkalian Pecahan

Menurut Arcavi (2003) visualiasasi merupakan proses dan hasil kreasi, interpretasi, penggunaan, dan refleksi gambar atau diagram, dalam pikiran, di atas kertas, atau dengan alat teknologi, dengan tujuan untuk menggambarkan, mengomunikasikan informasi, memikirkan, mengembangkan ide yang sebelumnya tidak diketahui, dan memajukan pemahaman.

Dengan visualisasi guru diharapkan untuk menyediakan lingkungan yang memaksimalkan belajar bersama penggunaan strategi dan pedagogi yang tepat (Nacy, 2012) karena setiap anak memiliki modalitas belajar yang bervariasi.

DePorter (2007) serta Suyono dan Hariyanto (2014) menjelaskan bahwa modalitas belajar dimaknai sebagai gaya belajar yang khas pada setiap individu. Salah satu modalitas belajar adalah visual. Seorang anak akan lebih cepat belajar dengan cara melihat.

Oleh karena itu, perlu pembelajaran yang mengaktifkan siswa berpikir. Menurut Pike (dalam Silberman, 2009) bahwa pembelajaran dengan menambahkan visual menaikkan ingatan $14 \%$ ke 38\%. Bahkan waktu yang diperlukan untuk menjelaskan konsep dapat berkurang sampai $40 \%$ ketika visual digunakan untuk menambah presentasi verbal (Silberman, 2009). 
Grinder (melalu Silberman, 2009) bahwa dari 30 siswa dalam 1 kelas, terdapat 22 siswa yang dapat belajar secara efektif selama guru menyediakan visual, auditory, dan aktivitas kinestetik.

Berdasarkan pendapat di atas, visualisasi dapat dikatakan proses penggunaan gambar visual untuk mengomunikasikan informasi guna memaksimalkan belajar siswa. Yang mana ada sebagian siswa memiliki modalitas belajar dengan visual, namun kurang terfasilitasi dengan baik. Sehingga dengan visualisasi diyakini efektif untuk membelajarkan sebuah konsep materi pecahan.

GAPTEK merupakan akronim dari GAris, Potong, TEmpel, dan Kalkulasi. Yaitu sebuah tahapan aktivitas motorik siswa melalui kegiatan menggambar, memotong, dan menempel. Aktivitas mental berupa melakukan kalkulasi (perhitungan) operasi pecahan melalui pengamatan visual.

Tujuan penelitian ini adalah mendeskripsikan bagaimana pembelajaran berbasis aktivitas materi operasi pecahan dengan menggunakan visualisasi GAPTEK dan mengetahui seberapa efektifkah pembelajaran berbasis aktivitas materi operasi pecahan dengan menggunakan visualisasi GAPTEK pada siswa kelas 7 SMP Negeri 3 Kepil.

\section{B. Metode}

Sukmadinata (2012) mengemukakan bahwa penelitian eksperimen adalah penelitian yang sifatnya menguji semua variabel menggunakan instrumen yang dibakukan. Pengujian ini untuk mengetahui apakah terjadi perubahan pada variabel terikat oleh perubahan pada variabel bebas. Oleh karena itu, semua variabel lain di luar variabel bebas harus dikontrol dengan menyamakan karakteristik sampel.

Penelitian ini menggunakan penelitian quasi eksperimen yang mana pada kelompok eksperimen diberikan perlakuan khusus, sedangkan pada kelompok kontrol diberikan perlakukan yang biasa dilakukan.

Subjek dalam penelitian ini adalah siswa kelas 7 SMP Negeri 3 Kepil. Pemilihan sampel dalam penelitian ini menggunakan teknik random sampling (Hadi, 2015). Teknik ini memberikan kesempatan yang 
sama untuk menjadi anggota sampel. Jadi, kelompok kontrol dan kelompok eksperimen haruslah dari kelompok kelas yang sama, yang membedakan hanyalah dari sisi perlakuan (Djiwandono, 2006).

Selanjutnya diambil secara acak 2 kelompok siswa, yang masingmasing berjumlah 30 siswa. Kelompok A merupakan kelompok kontrol sedangkan kelompok B merupakan kelompok eksperimen.

Menurut Sukmadinata (2012) reliabilitas mengukur tingkat keajegan/ ketetapan hasil pengukuran. Hadi (2015) menjelaskan bahwa teknik reliabilitas didasarkan pada perbandingan antara hasil-hasil pengukuran yang dilakukan berulang-ulang pada subjek yang sama.

Uji reliabilitas dengan membuat 2 instrumen ekuivalen (Sugiyono, 2015). Pengujian ini dilakukan pada 30 siswa selain kelas A dan B. dengan product moment. Dilihat $\mathrm{r}$ tabel dengan $\mathrm{n}=30$ dan taraf kesalahan $1 \%$ sebesar 0,463. Sedangkan hasil $r$ hitung didapatkan nilai 0,759 karena $r$ hitung > $r$ tabel yaitu, maka reliabel.

Validitas isi apabila butir telah mewakili aspek yang akan diukur. Sedangkan validitas konstruk diartikan apakah konstruk tersebut menjelaskan kesesuaian dengan teori (Sugiyono, 2015). Validitas sudah dikonsultasikan dengan ahli. Dengan demikian tes hasil belajar, sebagai salah satu instrumen penelitian dikatakan reliabel dan valid. Sehingga pretes dapat dimulai dengan mengambil 2 kelas (kelas eksperimen dan kelas kontrol) untuk mendapatkan skor hasil belajar.

Setelah dilakukan analisis data awal, didapatkan data sebagai berikut.

Tabel 1. Tests of Normality

\begin{tabular}{|l|c|c|c|c|c|c|}
\hline \multirow{2}{*}{} & \multicolumn{3}{|c|}{ Kolmogorov-Smirnova } & \multicolumn{3}{c|}{ Shapiro-Wilk } \\
\cline { 2 - 7 } & Statistic & Df & Sig. & Statistic & Df & Sig. \\
\hline Pre_Kelas_A & .146 & 30 & .101 & .946 & 30 & .135 \\
\hline Pre_Kelas_B & .153 & 30 & .069 & .950 & 30 & .172 \\
\hline
\end{tabular}

a. Lilliefors Significance Correction

Dari data di atas, hasil pretes kelas A maupun kelas B taraf siginifikansinya di atas 0,05 sehingga berdistribusi normal. 
Tabel 2: Uji Independent Samples Test

\begin{tabular}{|c|c|c|c|c|c|c|}
\hline & & & & \multicolumn{3}{|c|}{ Independent Samples Test } \\
\hline & & \multicolumn{2}{|c|}{$\begin{array}{l}\text { Levene's Test for Equality of } \\
\text { Variances }\end{array}$} & \multirow[b]{2}{*}{$t$} & \multirow[b]{2}{*}{ df } & \multirow[b]{2}{*}{ Sig. (2-tailed) } \\
\hline & & $\mathrm{F}$ & Sig. & & & \\
\hline \multirow[t]{2}{*}{ Hasil Pretes } & $\begin{array}{l}\text { Equal variances } \\
\text { assumed }\end{array}$ & \multirow[t]{2}{*}{.018} & \multirow[t]{2}{*}{.895} & \multirow[t]{2}{*}{-.574} & \multirow{2}{*}{$\begin{array}{r}58 \\
57.959\end{array}$} & \multirow{2}{*}{$\begin{array}{l}.569 \\
.569\end{array}$} \\
\hline & $\begin{array}{l}\text { Equal variances not } \\
\text { assumed }\end{array}$ & & & & & \\
\hline
\end{tabular}

Berdasarkan table di atas dapat diketahui bahwa nilai signifikansi 0,895 > 0,05 menunjukkan bahwa data kedua kelompok adalah homogen. Sedangkan nilai signifikansi perbedaan adalah 0,569>0,05 yang menunjukkan bahwa tidak ada perbedaan antara rata-rata pretes kelompok kontrol dan eksperimen.

Efektifitas pembelajaran berbasis aktivitas materi operasi pecahan dengan menggunakan visualisasi GAPTEK dinilai dengan :

1) Rata-rata postes kelas eksperimen $>70$

2) Rata-rata postes kelas eksperimen > rata-rata postes kelas kontrol

3) Perbedaan kenaikan rata-rata pretes dan postes kelas eksperimen

$>$ Perbedaan kenaikan rata-rata pretes dan postes kelas kontrol

Desain eksperimen (Arifin, 2012) merupakan suatu rancangan berisi langkah-langkah yang akan dilakukan dalam kegiatan penelitian eksperimen. Desain eksperimen digunakan dalam penelitian ini adalah control group pretes and postest design yaitu kelompok eksperimen dan kelompok kontrol mendapatkan pretes dan postes yang sama.

Teknik pengumpulan data selain menggunakan tes hasil belajar dilakukan dengan angket. Menurut Riyanto (2010) angket merupakan sejumlah pertanyaan yang harus dijawab oleh responden. Angket yang digunakan dalam penelitian ini merupakan angket tertutup yang mana pertanyaan/pernyataan beserta opsi jawaban sudah disediakan oleh penelitian, sehingga responden tinggal memilih.

Teknik pengumpulan data lainnya dilakukan dengan teknik observasi. Observasi merupakan teknik pengamatan dari suatu kegiatan yang $532\}$ Ditjen GTK Pendidikan Dasar Kemendikbud R.I 
sedang berlangsung. Pedoman observasi disusun dalam penelitian ini menggunakan bentuk pertanyaan yang disusun secara tidak sitematis. Observasi dalam penelitian ini digunakan untuk mendeskripsikan pembelajaran berbasis aktivitas yang dilaksanakan.

\section{Hasil dan Pembahasan}

Dalam pembelajaran ini alat dan bahan yang digunakan adalah : (1) spidol boardmaker; (2) kertas mika; (3) kertas berpetak; (4) penggaris; (5) gunting; (6) lem kertas; (7) alat tulis.

Alat dan bahan terlihat di bawah ini :

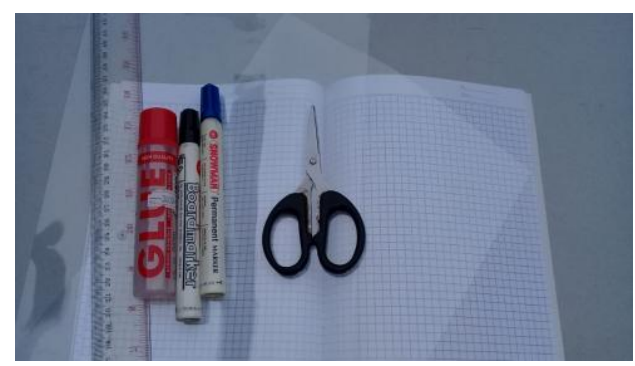

Gambar 5. Alat dan Bahan GAPTEK

Secara deskripsi pembelajaran diawali dengan memberikan desain pebelajaran yang berkaitan tentang alat dan bahan ajar yang akan digunakan, waktu, serta hal-hal yang harus dilakukan yang terangkum dalam LKPD (Lembar Kerja Peserta Didik). Pembelajaran ini dipandu dalam 2 kali tatap muka virtual dengan perencanaan operasi materi pecahan berupa penjumlahan dan pengurangan pada pertemuan 1 dan operasi pecahan perkalian pada pertemuan 2 .

Kegiatan penelitian diawali dengan perencanaan. Perencanaan tersebut meliputi analisis KI/KD matematika kelas VII pada kurikulum balitbang, pemilihan topik penelitian, pembuatan LKPD (Lembar kerja Peserta Didik), perencanaan objek dan waktu penelitian, penyiapan alat dan bahan, serta simulasi praktik pembelajaran berbasis aktivitas. 
Grup WA dibentuk memudahkan guru dan siswa untuk terlibat aktif dalam proses pembelajaran. Siswa beberapa kali bertanya via Wapri, sekalipun diberikan kesempatan bertanya melalui grup WA yang disediakan.

Dipilihnya materi operasi pecahan karena selama ini pembelajaran operasi pecahan lebih pada pembelajaran menggunakan ceramah serta siswa menghafal rumus atau formula yang diberikan. Akibatnya kesan bermakna saat belajar tidak didapatkan oleh siswa.

Pada pelaksanaan penelitian, pembelajaran diawali dengan memberikan desain pembelajaran yang berkaitan tentang alat dan bahan ajar yang akan digunakan, waktu, serta hal-hal yang harus dilakukan yang terangkum dalam LKPD. Pembelajaran ini dipandu dalam 2 kali tatap muka virtual dengan perencanaan operasi materi pecahan berupa penjumlahan dan pengurangan pada pertemuan 1 dan operasi pecahan perkalian pada pertemuan 2 .

Waktu penelitian dilakukan pada pertengahan September 2020 dengan objek siswa kelas VII tahun pelajaran 2020/2021 semester ganjil yang terhubung dalam grup WA. Selanjutnya dipilih 30 siswa untuk menjadi kelas eksperimen secara random, sedangkan 30 siswa lainnya menjadi kelas kontrol. Siswa sisanya melakukan pembelajaran sebagaimana kelas kontrol, hanya tidak dilakukan pengambilan sampel sebagai kelas kontrol.

Pembelajaran ini dapat dilakukan secara individual maupun kelompok dengan maksimal anggota 4 anak. Dari sini, didapatkan ada 8 kelompok. Pembelajaran dilakukan secara daring dengan panduan konsultasi via WA grup. Guru membentuk grup siswa dengan kelompok eksperimen dan grup siswa kelompok kontrol untuk memudahkan komunikasi guru dengan siswa.

Melalui LKPD yang diberikan, siswa diberi kesempatan untuk mengeksplorasi sesuai dengan bahan belajar yang ada di buku paket, yaitu di buku paket matematika Kemendikbud halaman 53-68.

Keperluan dokumentasi, dipilih satu kelompok siswa yang mengerjakan di rumah, sedangkan untuk observasi dilakukan di ruang keterampilan SMP Negeri 3 Kepil. Selanjutnya dilakukan pengamatan (observasi) untuk mendapatkan data penelitian dengan diberikan lembar observasi (berkaitan 
proses) tidak sistematis karena hanya berupa rambu-rambu. Sedangkan angket (berkaitan respon siswa) diberikan dengan instrumen angket tertutup.

Hasil dokumentasi pembelajaran berbasis aktivitas menggunakan visualisasi GAPTEK disajikan berikut ini.

\section{Aktivitas 1}

Penjumlahan $\frac{1}{3}+\frac{2}{3}$

Siswa mula-mula membuat gambar persegi panjang berukuran $2 \times 12 \mathrm{~cm}$ di kertas berpetak. Lalu garis menjadi 3 bagian yang sama untuk menunjukkan 1 bagian dari bagian yang ada. Tempelkan kertas mika di atasnya, lalu gunting. Setelah digunting, buat menjadi 3 bagian lalu arsir. Lakukan sebanyak 2 kali. Pada potongan pertama arsir menjadi pecahan $\frac{1}{3}$ sedangkan pada potongan kedua arsir menjadi pecahan $\frac{2}{3}$.

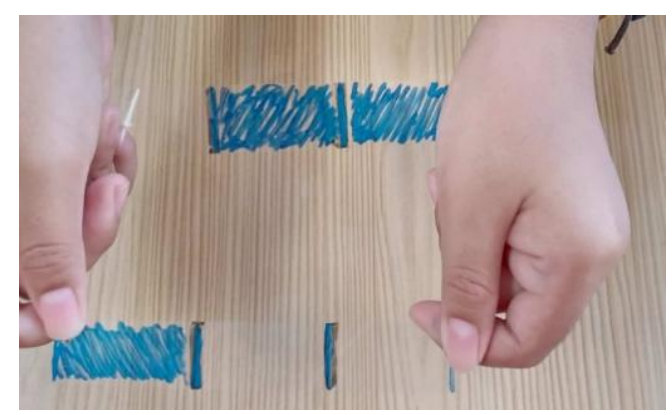

Gambar 6. Aktivitas Visualisasi 1.1

Selanjutnya jumlahkan dengan cara menempelkan potongan pertama dengan potongan kedua.

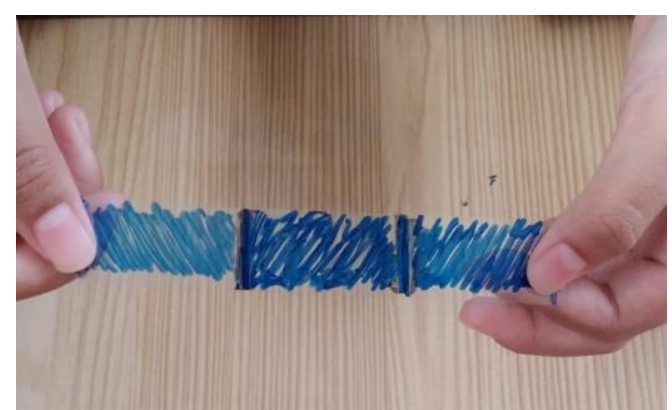

Gambar 7. Aktivitas Visualisasi 1.2 
Dari gambar di atas, terdapat 3 arsiran, yang masing-masing arsiran bernilai $\frac{1}{3}$. Dengan demikian hasilnya yang diperoleh adalah $\frac{3}{3}$. Pada aktivitas 1 ini siswa masih kesulitan dan ragu untuk menggunting, menggambar, serta menempel. Para siswa terlihat beberapa kali ragu mengambil keputusan karena ada ketakutan melakukan kesalahan.

\section{Aktivitas 2}

\section{Penjumlahan $\frac{2}{5}+\frac{4}{5}$}

Siswa terlebih dahulu membuat persegi panjang yang berukuran 2 x $20 \mathrm{~cm}$ pada kertas berpetak. Lalu garis menjadi 5 bagian yang sama ukurannya. Artinya 1 kotak berukuran $2 \times 4 \mathrm{~cm}$. Satu bagian yang sama tadi menunjukkan pecahan $\frac{1}{5}$.

Tempelkan kertas mika di atasnya, lalu gunting. Setelah digunting, buat menjadi 5 bagian lalu arsir. Lakukan sebanyak 2 kali. Pada potongan pertama arsir menjadi pecahan $\frac{2}{5}$ sedangkan pada potongan kedua arsir menjadi pecahan $\frac{4}{5}$.

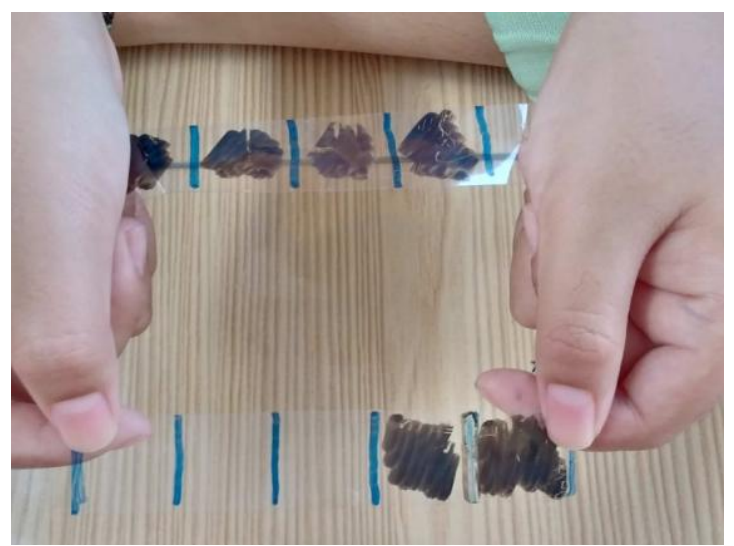

Gambar 8. Aktivitas Visualisasi 2.1

Selanjutnya jumlahkan dengan cara menempelkan potongan pertama dengan potongan kedua. 


\section{Aktivitas 3}

\section{Penjumlahan $\frac{2}{5}+\frac{1}{2}$}

Siswa terlebih dahulu membuat persegi panjang yang berukuran 2 x $20 \mathrm{~cm}$ pada kertas berpetak. Lalu garis menjadi 5 bagian yang sama ukurannya. Artinya, 1 kotak berukuran $2 \times 4 \mathrm{~cm}$. Satu bagian yang sama tadi menunjukkan pecahan $\frac{1}{5}$.

Selanjutnya, gambar lagi persegi panjang yang berukuran $2 \times 20 \mathrm{~cm}$ pada kertas berpetak. Lalu garis menjadi 2 bagian yang sama ukurannya. Artinya 1 kota berukuran $2 \times 10 \mathrm{~cm}$. Satu bagian yang sama menunjukkan pecahan $\frac{1}{2}$.

Tempelkan kertas mika di atasnya, lalu gunting. Setelah digunting, buat menjadi 5 bagian dan mika yang kedua gunting menjadi 2 bagian. Pada potongan pertama arsir menjadi pecahan $\frac{2}{5}$ sedangkan pada potongan kedua arsir menjadi pecahan $\frac{1}{2}$.

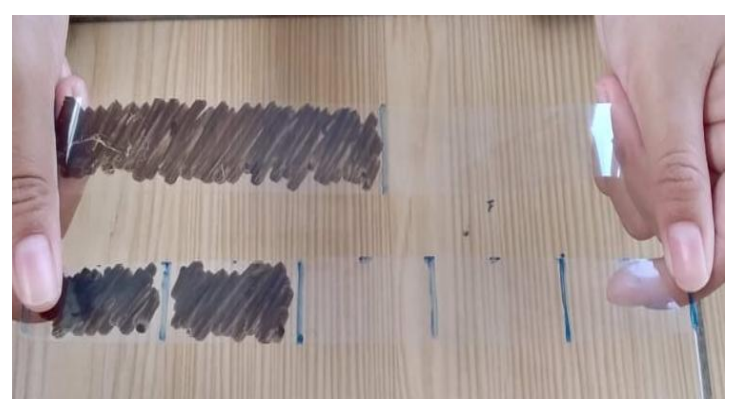

Gambar 9. Aktivitas Visualisasi 3

Selanjutnya kalkulasikan dengan menjumlahkan menggunakan cara menempelkan potongan pertama dengan potongan kedua.

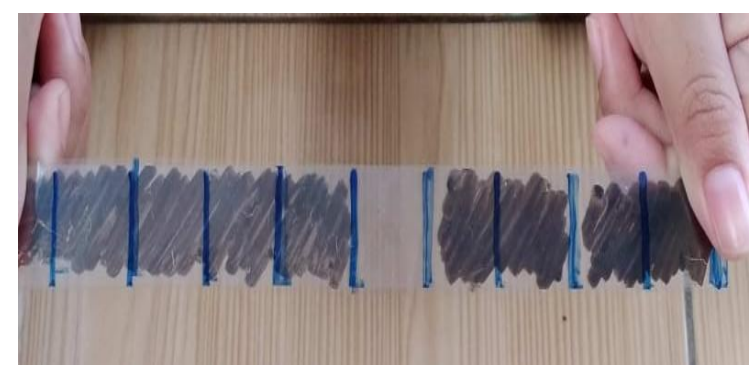

Gambar 10. Aktivitas Visualisasi 3.1 
Dengan membuat lagi 1 gambar mika berukuran $2 \times 20 \mathrm{~cm}$, yang dibagi ke dalam 10 potong dengan masing-masing potongan berukuran 2 x $2 \mathrm{~cm}$. Dari gambar di atas, terlihat bahwa ketika 3 mika diiriskan, akan didapatkan pecahan $\frac{9}{10}$. Hal ini bisa dijelaskan dari pecahan senilai $\frac{1}{2}=\frac{5}{10}$ dan $\frac{2}{5}=\frac{4}{10}$. Pada aktivitas di atas, siswa sudah tidak lagi kesulitan.

\section{Aktivitas 4}

Pengurangan $\frac{1}{2}-\frac{2}{5}$

Siswa terlebih dahulu membuat persegi panjang yang berukuran 2 x $20 \mathrm{~cm}$ pada kertas berpetak. Lalu garis menjadi 5 bagian yang sama ukurannya. Artinya 1 kotak berukuran $2 \times 4 \mathrm{~cm}$. Satu bagian yang sama tadi menunjukkan pecahan $\frac{1}{5}$.

Selanjutnya, gambar lagi persegi panjang yang berukuran $2 \times 20 \mathrm{~cm}$ pada kertas berpetak. Lalu garis menjadi 2 bagian yang sama ukurannya. Artinya 1 kota berukuran $2 \times 10 \mathrm{~cm}$. Satu bagian yang sama menunjukkan pecahan $\frac{1}{2}$.

Tempelkan kertas mika di atasnya, lalu gunting. Setelah digunting, buat menjadi 5 bagian dan mika yang kedua gunting menjadi 2 bagian. Pada potongan pertama arsir menjadi pecahan $\frac{2}{5}$ sedangkan pada potongan kedua arsir menjadi pecahan $\frac{1}{2}$.

Karena bentuknya pengurangan, maka langkah kalkulasinya dengan mengambil arisaran yang terdapat pada pecahan $\frac{1}{2}$.

\section{Aktivitas 5}

Perkalian $\frac{1}{2} \times \frac{4}{5}$

Siswa terlebih dahulu membuat persegi panjang yang berukuran 2 x $20 \mathrm{~cm}$ pada kertas berpetak. Lalu garis menjadi 5 bagian yang sama ukurannya. Artinya 1 kotak berukuran $2 \times 4 \mathrm{~cm}$. Satu bagian yang sama tadi menunjukkan pecahan $\frac{1}{5}$. 
Selanjutnya, gambar lagi persegi panjang yang berukuran $2 \times 20 \mathrm{~cm}$ pada kertas berpetak. Lalu garis menjadi 2 bagian yang sama ukurannya, dengan pola melintang. Artinya 1 kotak berukuran 1 × $20 \mathrm{~cm}$. Satu bagian yang sama menunjukkan pecahan $\frac{1}{2}$.

Tempelkan kertas mika di atasnya, lalu gunting. Setelah digunting, buat menjadi 5 bagian dan mika yang kedua gunting menjadi 2 bagian. Pada potongan pertama arsir menjadi pecahan $\frac{4}{5}$ sedangkan pada potongan kedua arsir menjadi pecahan $\frac{1}{2}$.

Selanjutnya dengan cara menempelkan potongan pertama dengan potongan kedua lalu hitunglah bagian yang beririsan. Sebagaimana terlihat dalam gambar di bawah ini.

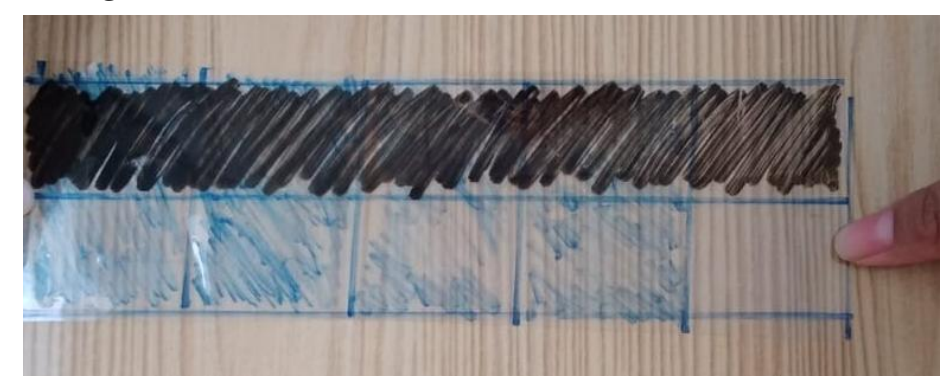

Gambar 11. Aktivitas Visualisasi 5

\section{Aktivitas 6}

Perkalian $\frac{3}{10} \times \frac{1}{5}$

Siswa terlebih dahulu membuat persegi panjang yang berukuran 5 x $20 \mathrm{~cm}$ pada kertas berpetak. Lalu garis menjadi 10 bagian yang sama ukurannya. Artinya, 1 kotak berukuran $5 \times 2 \mathrm{~cm}$. Satu bagian yang sama tadi menunjukkan pecahan $\frac{3}{10}$.

Gambar lagi persegi panjang yang berukuran $5 \times 20 \mathrm{~cm}$ pada kertas berpetak. Lalu garis menjadi 5 bagian yang sama ukurannya, dengan pola melintang. Artinya 1 kotak berukuran $1 \times 20 \mathrm{~cm}$. Satu bagian yang sama menunjukkan pecahan $\frac{1}{5}$. 
Tempelkan kertas mika di atasnya, lalu gunting mengikuti ukuran kertas berpetak yang sudah dibuat. Selanjutnya digaris dan diarsir mengikuti yang sudah dibuat di kertas berpetak.

Selanjutnya dengan cara menempelkan potongan pertama dengan potongan kedua lalu hitunglah bagian yang beririsan. Sebagaimana terlihat dalam gambar di bawah ini.

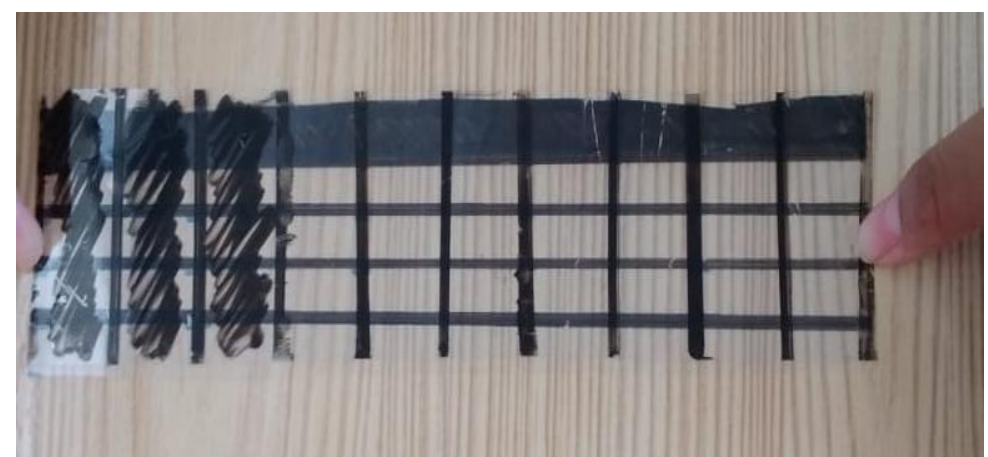

Gambar 12. Aktivitas Visualisasi 6

Hasil observasi menunjukkan bahwa semua siswa terlibat aktif selama proses PBA ini. Siswa aktif berdiskusi dan berkolaborasi untuk memecahkan permasalahan yang diberikan, yaitu mengoperasikan pecahan dengan visualisasi.

Terdapat siswa yang mengatur jalannya kegiatan dengan memberikan arahan pada siswa lain untuk melakukan kegiatan pengguntingan dan menggambar. Ada juga siswa yang mengamati dan mencatat.

Awalnya siswa masih ragu dan kesulitan dalam menggambar dan menggunting. Mulai aktivitas 3, siswa sudah lancar dalam melakukan kegiatan menggambar hingga mengkalkulasi. Hanya saja, beberapa siswa terutama siswa yang sudah mampu menjumlahkan pecahan tanpa visualisasi lebih cenderung kurang memperhatikan dibanding dengan siswa lain.

Selanjutnya guru meminta siswa mulai mengabstraksi berdasarkan kegiatan yang sudah dilaksanakan dengan memberikan beberapa soal yang setipe. 
Siswa tidak lagi tergantung buku teks dalam menjawab soal. Siswa mampu memvisualisasi secara abstraksi pengerjaan soal dengan menuliskan di buku catatan setelah dikuatkan dengan pengalaman langsung menggunting, menggambar, dan menempel. Siswa terlihat beberapa kali membaca LKPD dan buku paket sebagai panduan serta tidak segan untuk berkonfirmasi kepada guru.

Hasil rekapitulasi angket respon positif pada kelas eksperimen sebagai berikut :

Tabel 3. Rekapitulasi Angket Respon Positif PBA

\begin{tabular}{|c|c|c|c|c|}
\hline \multirow[b]{2}{*}{ No } & \multirow[b]{2}{*}{ Pernyataan } & \multicolumn{2}{|c|}{ Respon Siswa } & \multirow[b]{2}{*}{$\begin{array}{l}\text { Persentase } \\
\text { Respon Positif }\end{array}$} \\
\hline & & $\begin{array}{c}\text { Ya } \\
\text { (Positif) }\end{array}$ & $\begin{array}{c}\text { Tidak } \\
\text { (Negatif) }\end{array}$ & \\
\hline 1. & Saya senang mengikuti pembelajaran sampai akhir & 30 & 0 & $100 \%$ \\
\hline 2. & $\begin{array}{l}\text { Saya mendapatkan sesuatu yang bermakna setelah } \\
\text { melakukan semua aktivitas }\end{array}$ & 30 & 0 & $100 \%$ \\
\hline 3. & Saya terlibat aktif dalam diskusi & 25 & 5 & $83,3 \%$ \\
\hline 4. & Saya lebih percaya diri saat pembelajaran berlangsung & 27 & 3 & $90 \%$ \\
\hline 5. & Saya merasa mendapatkan sesuatu yang baru & 30 & 0 & $100 \%$ \\
\hline 6. & Saya merasa pembelajaran ini bermanfaat & 30 & 0 & $100 \%$ \\
\hline 7. & Saya merasa nyaman belajar & 30 & 0 & $100 \%$ \\
\hline 8. & Saya bersemangat melakukan pembelajaran ini & 28 & 2 & $93,3 \%$ \\
\hline 9. & $\begin{array}{l}\text { Saya berani bertanya ketika ada hal sulit yang } \\
\text { kutemui }\end{array}$ & 26 & 4 & $86,7 \%$ \\
\hline 10. & Saya ingin pembelajaran seperti ini & 30 & 0 & $100 \%$ \\
\hline \multicolumn{4}{|c|}{ Persentase rata-rata respon positif siswa } & $95,3 \%$ \\
\hline
\end{tabular}

Berdasarkan tabel di atas, respon positif siswa secara sempurna yaitu siswa senang mengikuti pembelajaran sampai akhir, siswa mendapatkan sesuatu yang bermakna, sesuatu yang baru, ada manfaat, kenyamanan, dan keinginan pembelajaran serupa dilakukan ulang.

Terlihat di atas bahwa persentase rata-rata respon positif siswa terkait pembelajaran berbasis aktivitas materi operasi pecahan menggunakan visualisasi GAPTEK sebesar 95,3\%. Hal ini sejalan dengan tujuan pembelajaran berbasis aktivitas yaitu membuat kelas lebih ramah siswa dan siswa tidak merasa terintimidasi (Kapur, 2019).

Hasil respon positif di atas menunjukkan bahwa siswa terlibat aktif dalam pembelajaran berbasis aktivitas. Siswa merasa nyaman, terbuka, dan 
mendapat kesempatan mengembangkan diri melalui aktivitas yang dilakukan. Hal ini sejalan dengan apa yang disampaikan oleh Suyono danHariyanto (2014) bahwa belajar itu siswa yang melakukan aktivitas dan siswa harus terlibat aktif di dalam kegiatan pembelajaran yang dilakukan.

Respon siswa ada 4 yang menunjukkan tidak berani bertanya ketika pembelajaran berbasis aktivitas ini dilakukan. Hal ini masih lebih baik, jika dibandingkan ketika pembelajaran tatap muka di kelas, yang mana masih banyak sekali siswa yang takut bertanya. Sejatinya, siswa tidak paham terhadap materi yang diberikan. Namun, dengan diberikannya pembelajaran berbasis aktivitas ini, siswa menjadi lebih berani bertanya.

Setelah selesai kegiatan pembelajaran berbasis aktivitas materi operasi pecahan menggunakan visualisasi GAPTEK, dilakukan kegiatan penilaian hasil belajar dengan memberikan tes sebanyak 10 item soal. Instrumen tes diberikan kepada 2 kelompok yaitu kelas A dan kelas B. Soal tes ini diberikan lewat foto WA. Siswa mengerjakan dengan batas waktu yang sudah ditentukan.

Hasil penelitian dapat ditunjukkan dalam tabel berikut.

Tabel 4. Descriptve Statistics

\begin{tabular}{|l|l|c|c|c|c|}
\hline & $\mathrm{N}$ & Minimum & Maximum & Mean & Std. Deviation \\
\cline { 3 - 6 } Pretes Kelas A & 30 & 10 & 60 & 35.00 & 13.326 \\
Pretes Kelas B & 30 & 10 & 70 & 37.00 & 13.684 \\
Postes Kelas A & 30 & 40 & 80 & 56.00 & 11.919 \\
Postes Kelas B & 30 & 40 & 100 & 74.33 & 16.121 \\
Valid N (listwise) & 30 & & & & \\
\hline
\end{tabular}

Tabel di atas menunjukkan bahwa rata-rata kelas eksperimen sebesar 74,33 sudah melampaui batas KKM kelas yaitu 70,00.

Rata-rata nilai siswa di kelas eksperimen yang sudah melampaui KKM menunjukkan bahwa secara umum pembelajaran sudah berhasil dari sisi ketuntasan kelas. Meskipun masih didapati siswa yang belum tuntas secara individu. Rencana tindak lanjut yang akan dilakukan oleh guru adalah memberikan kesempatan ulang untuk dilakukan remidi dengan memberikan kesempatan pada siswa yang tidak tuntas belajar materi yang diberikan melalui aktivitas yang diulang. 
Berdasarkan tabel di atas pula, nilai rata-rata pretes kelas A (kontrol) adalah 35,00 sedangkan nilai rata-rata postesnya sebesar 56,00. Terjadi perbedaan kenaikan rata-rata sebesar 21,00. Nilai rata-rata kelas B (eksperimen) adalah 37,00 , sedangkan nilai rata-rata postesnya adalah 74,33 . Hal ini telah terjadi perbedaan kenaikan rata-rata sebesar 37,33.

Secara ringkas hasil belajar siswa adalah sebagai berikut. (1) ratarata kelas eksperimen adalah 74,33 melampaui nilai 70,00; (2) Rata-rata kelas eksperimen yaitu 74,33 lebih dari rata- rata kelas kontrol yaitu 56,00; dan (3) Perbedaan kenaikan rata-rata pretes dan postes kelas eksperimen sebesar 37,33 (skala interval 0-100) lebih dari perbedaan kenaikan ratarata pretes dan postes kelas kontrol sebesar 21,00 (skala interval 0-100).

Berdasarkan capaian hasil belajar di atas, dapat dimaknai bahwa pembelajaran berbasis aktivitas telah berhasil menuntaskan kompetensi operasi pecahan baik itu operasi penjumlahan, pengurangan, dan perkalian secara visualisasi.

Dengan demikian, pembelajaran berbasis aktivitas efektif digunakan dalam pembelajaran di kelas materi operasi pecahan menggunakan visualisasi GAPTEK. Hal ini sejalan dengan tujuan pembelajaran berbasis aktivitas (Kapur, 2019) serta Grinder\&Pike (dalam Silberman, 2009) tentang manfaat belajar secara visual serta.

Capaian kompetensi yang sudah didapat ini, akan menjadi lebih bermakna di mata para siswa. Harapannya, untuk materi operasi pecahan terkait dengan pembagian, dapat dilaksanakan untuk pertemuan selanjutnya. Mengingat materi operasi pembagian dengan visualisasi dibutuhkan materi prasyarat yaitu penjumlahan, perkalian, dan perkalian.

\section{Penutup}

Pembelajaran berbasis aktivitas (PBA) merupakan proses belajar terpusat pada siswa yang melibatkan aspek mental dan psikomoter melalui beragam pengalaman. Pembelajaran berbasis aktivitas dalam penelitian ini dengan memilih materi operasi pecahan dengan menggunakan 
visualisasi GAPTEK, yaitu aktivitas fisik menggaris, memotong, menempel, dan mengalkulasi.

Deskripsi pembelajaran menunjukkan bahwa siswa terlibat aktif dalam diskusi kelompok. Siswa berbagi peran dalam GAPTEK (Gambar, Potong, Tempel, dan Kalkulasi) yaitu menggambar, memotong, menempel, dan mengkalkulasi. Awalnya siswa masih ragu dan takut dalam beraktivitas, namun lama-kelamaan menjadi terbiasa. Selanjutnya guru meminta siswa mengabstraksi operasi pecahan dengan memberikan soal yang setipe.

Persentase rata-rata respon positif siswa terkait pembelajaran berbasis aktivitas materi operasi pecahan menggunakan visualisasi GAPTEK sebesar 95,3\%. Pembelajaran berbasis aktivitas telah efektif digunakan terbukti dari (1) rata-rata kelas eksperimen adalah 74,33 melampaui nilai 70,00, (2) rata-rata kelas eksperimen yaitu 74,33 lebih dari rata-rata kelas kontrol yaitu 56,00, dan (3) perbedaan kenaikan rata-rata pretes dan postes kelas eksperimen sebesar 37,33 (skala interval 0-100) lebih dari perbedaan kenaikan rata-rata pretes dan postes kelas kontrol sebesar 21,00 (skala interval 0-100).

Makna dari kefektivan di atas, tentu saja hanya berlaku pada populasi terbatas siswa kelas VII di SMPN 3 Kepil. Jadi tidak bisa digeneralisasi untuk populasi secara umum di sekolah lain.

Pencapaian ketuntasan kelas pada kelas eksperimen akan diterapkan pada kelas kontrol, serta siswa yang tidak tuntas pada kelas eksperimen akan diberikan perlakuan yang sama sebagaimana kelas eksperimen.

Dalam pembelajaran aktivitas materi operasi pecahan, beberapa siswa yang sudah menguasai materi justru terlihat kurang aktif dibandingkan siswa yang lain. Oleh karena itu, penulis menyarankan cara mengatasinya dengan memperkuat pemahaman siswa dengan cara lain, yaitu dengan aktivitas visual. Saran lain, guru perlu mendesain rancangan pembelajaran berbasis aktivitas dalam materi-materi yang lainnya.

\section{Ucapan Terima Kasih}

Terimakasih saya sampaikan kepada Kemendikbud terutama kepada Dirjen GTK Dikdas, Kepala Disdikpora Kab. Wonosobo, Pengawas 
SMP Negeri 3 Kepil, Kepala SMP Negeri 3 Kepil, beserta teman-teman guru yang telah berperan penting membantu penulisan artikel ilmiah ini. Tidak lupa kami sampaikan ucapan terima kasih atas dukungan kepada teman-teman Finalis Inobel SMP MIPA yang terus-menerus memberikan motivasi hingga terselesainya penulisan ini.

\section{Daftar Referensi}

Anwer, Fizza. (2019). Activity-Based Teaching, Student Motivation and Academic Achievement. Jurnal Journal of Education and Educational Development , 6 (1).

Arcavi, A.(2003).The Role of Visual Representations in the Learning of Mathematics Educational Studies in Mathematics 52, 215-241. https://doi.org/10.1023/A:1024312321077.

Arifin, Zainal. (2012). Penelitian Pendidikan Metode dan Paradigma Baru. Bandung: Remaja Rosdakarya.

As'ari, dkk. (2016). Matematika Kelas VII Semester 1 Kurikulum 2013. Jakarta : Puskurbuk Kemdikbud.

DePorter, Bobbi. (2007). Quantum Learning. ed terjemah. Bandung:Kaifa Djiwandono, Sri Esti Wuryani. (2006). Psikologi Pendidikan. Jakarta : Gramedia Hadi, Sutrisno. (2015). Metodologi Riset. Yogyakarta : Pustaka Pelajar.

Hudojo, Herman. (2005). Pengembangan Kurikulum dan Pembelajaran Matematika. Malang : UM Press.

Kapur, Radhika. (2019). Activity-Based Learning through Digital Schools. Diakses tanggal 14 Agustus 2020 tersedia di https://www. researchgate.net/publication/333557467_ActivityBased_Learning_through_Digital_Schools.

Mulyasa. (2013). Praktik Penelitian Tindakan Kelas. Bandung : Remaja Rosdakarya. Munthe, Bermawy. (2014). Desain Pembelajaran. Yogyakarta : Pustaka Insan Madani.

Nacy,etc. (2012). Students' Visual Representation of Mathematics. Diakses tanggal 14 Agustus 2020 tersedia di https://www. researchgate. net/publication/263362000

Riyanto, Yatim. (2010). Metodologi Penelitian Pendidikan. Surabaya : Penerbit SIC 
Silberman, Melvin L. (2009). Ed.Terjemah. Yogyakarta: Pustaka Insan Madani.

Sugiyono. (2015). Statistika untuk Penelitian. Bandung : Alfabeta.

Sukmadinata, Nana Syaodih. (2012). Metode Penelitian Pendidikan. Bandung : Remaja Rosdakarya.

Supriadie., \& Darmawan. (2013). Komunikasi Pembelajaran. Bandung : Remaja Rosdakarya.

Suprijono. (2012).Coperative Learning Teori dan Aplikasi PAIKEM. Yogyakarta : Pustaka Pelajar.

Suryadi, Ace. (2014). Pendidikan Indonesia Menuju 2025. Bandung : Remaja Rosdakarya.

Suyono., \& Hariyanto. (2014).Belajar dan Pembelajaran. Bandung : Remaja Rosdakarya.

Tabrani ZA. (2014). Dasar-Dasar Metodologi Penelitian Kualitatif. Yogyakarta: Darussalam Publishing.

Wena, Made. (2012). Strategi Pembelajaran Inovatif Kontemporer Suatu Tinjauan Konseptual Operasional. Jakarta : Bumi Aksara. 